UDC (517.977.5)

I. Parkhomei, D. Humennyi, M. Tkach, V. Payun, Y. Bondar

\title{
OPTIMAL CONTROL SYSTEMS DESIGN OF COMMUNICATION NETWORKS
}

Abstract: the principles of control systems' optimal design are given while it is running two main modes: stationary and automatic. The search methods of decisions in accordance with these modes are offered.

Keywords: optimal systems, minimax, minimin, risk minimization, communication networks, TMN, SMS

\section{Introduction}

While designing control of the communication networks, it is supposed, that static characteristics of an entrance signal are set [1]. The task consists of searching of system strategy which is promoted by an extreme criterion of optimality.

The design problem of optimal system should be considered.

\section{Main part}

In Telecommunication Management Network (TMN) control system, during exchange of information between input parameters of controlled objects and the Security Management operating System (SMS), it is expedient to review two main modes. The first is the stationary mode during which control parameters of the operated network is exercised. The second is an emergency mode in which it is possible to define probabilities of the possible signals which are received by SMS and are generated by parameters of objects. In such conflict situations it is expedient to design a control system under adverse signals' values.

Two tasks, which are arising during design of the system, are formulated below.

\section{Minimin optimal system}

The rate $\Omega_{1}(\lambda)$ of signal and interference characteristic are known.

It is necessary to find from a signal rate $\Omega_{1}(\lambda)$ and a functions rate $\Omega_{2}(\rho)$ signal values $\lambda=\lambda^{*}$ and function values $\rho=\rho^{*}$ that provide minimum of risk.

\footnotetext{
${ }^{\circledR}$ I. Parkhomei, D. Humennyi, M. Tkach, V. Payun, Y. Bondar
} 
Analytically this task is described by the formula:

$$
r\left(\lambda^{*}, \rho^{*}\right)=\min _{\rho \in \Omega_{2}(\rho)}-\min _{\lambda \in \Omega_{1}(\lambda)} r(\lambda, \rho) .
$$

We define this task as minimin, and the system which is possessed by a minimum of risk (1) as minimin optimal system. Minimin optimal system is the best of all systems which works in the conditions of the given interferences in admissible area $\Omega_{1}(\lambda)$. The expressions for the system risk is described below. The system entrance signal represents the sum of a useful signal $\lambda$ and interference $N$ :

$$
X=\lambda+N
$$

The interference $N$ is accidental and has probability density $f_{n}$. The useful signal $\lambda$ is chosen in admissible area $\Omega_{1}(\lambda)$.

Since in this task a useful signal is nonrandom, then in a formula of the average risk it is necessary to accept useful signal $\Omega_{1}(\lambda)$ probability density as $\delta$-functions:

$$
f_{1}(\lambda)=\delta\left(\lambda-\lambda^{*}\right)
$$

Thus conditional risk law

$$
r(\lambda, \rho)=\int_{\Omega(x, y)} \theta[H\{\lambda\}, y] f_{2}\left(\frac{x}{\lambda}\right) \rho\left(\frac{y}{x}\right) d \Omega,
$$

where $H\{\lambda\}$ is the useful signal transformation area.

In the case, when strategy of system is determined [2] as $\rho(y / x)=\delta\left(y-y^{*}\right)$ and with taking into account properties of $\delta$-functions formula (3) becomes:

$$
r(\lambda, A)=\int_{\Omega(x)} \theta\left[\int H\{\lambda\}, A\{x\}\right] f_{2}(x / \lambda) d x,
$$

where $A$ - the determined operator of system.

The task of minimin system optimization consists in finding such values, for which the risk (4) is minimal, among all signals from $\Omega_{1}(\lambda)$ and functions from $\Omega_{2}(\rho)$ :

$$
r\left(\lambda^{*}, A^{*}\right)=\min _{A \in \Omega_{2}(A)} \min _{\lambda \in \Omega_{1}(\lambda)} \int_{\Omega(x)} \theta[H\{\lambda\}, A\{x\}] f(x / \lambda) d x .
$$

The distribution of a signal conditional density $f_{2}(x / \lambda)$ relative to the useful signal $\mathrm{X}$ is on density of probability of a interference $N$ and a way of a signals and interferences combination (2) [3]. 
When the operator $A$ is set and expression of a signal is given as $\lambda=\lambda(a, t)$, where parameter $a$ is subject to definition, the solution of a task is reduce to find the minimum of function (4) by the parameter $a$.

From a minimization condition of function $\frac{\partial r}{\partial a}=0$ the value $a=a^{*}$ is found. The risk is minimal by this value.

It is possible to assume, that minimin optimal system, during distribution of signal $f_{1}=f_{1}^{*}$ and solution function $\rho_{1}=\rho_{1}{ }^{*}$ is located in areas $\Omega_{1}\left(f_{1}\right)$ and $\Omega_{2}(\rho)$, which provide a minimum of average risk:

$$
R\left(f_{1}^{*}, p^{*}\right)=\min _{p \in \Omega_{2}(p)} \min _{f_{1} \in \Omega_{1}\left(f_{1}\right)} R\left(f_{1}, p\right) .
$$

In such way, minimin optimal system in condition (5) is the best of all systems, which works in the interferences conditions and at the favorable law of distribution of an entrance signal from the admissible area of distributions $\Omega_{1}\left(f_{1}\right)$.

\section{Minimax optimal system}

The area $\Omega_{1}(\lambda)$ of signal and the interference characteristic values is known. It is necessary to find from a set of functions $\Omega_{1}(\lambda)$ next:

$$
\max _{\lambda \in \Omega_{1}(\lambda)} r\left(\lambda, p^{*}\right)=\min _{p \in \Omega_{2}(p)} \min _{\lambda \in \Omega_{1}(\lambda)} r(\lambda, p) \text {. }
$$

In this case there is talk of some vector synthesis [4, 5], when through estimations it is possible to choose quality indicators. Thus as optimal, we realize system $S_{M}$, for which the inequality (6) is carried out as

$$
\begin{gathered}
K_{\text {max }}^{\prime}\left(S_{M}\right) \leq K_{\text {max }}^{\prime}(S), \\
S, S_{M} \in M_{S D},
\end{gathered}
$$

where $M_{S D}$ - a set of admissible systems,

$K_{\max }^{\prime}=\max _{i}\left(K_{1}^{\prime}, \ldots, K_{i}^{\prime}, \ldots, K_{m}^{\prime}\right)$-the greatest indicator of quality $\left(K^{\prime}, \ldots, K_{i}^{\prime}, \ldots, K_{m}^{\prime}\right)$.

The minimax criteria provide the best value from the greatest of quality indicators.

From (6) follows, that the minimax decision is found for among a set $M_{S D}$ of admissible decisions. The required decision does not change when search procedure is broken into two stages. 
At the first stage the minimax decision $S_{M}$ is found for among admissible systems $M_{D}$, in (6) instead of $S \in M_{S D}$ when $S \in M_{D}$. At this stage restrictions $O_{k}$ on values of indicators of quality $K_{1}, \ldots, K_{m}$ are not consider.

At the second stage performance of a condition are checked

$$
K^{\prime}{ }_{\max }\left(S_{M}\right) \leq 1 .
$$

If this condition is satisfied, also next condition is satisfied

$$
K_{i}{ }^{\prime}=K_{i} / K_{i m} \leq 1, i=\overline{1, m} .
$$

Therefore, the search of minimax system is admissible and belongs to a set.

If it appears that the inequality (7) is not carried out, it means, that conflicting data are chosen, as minimization of the greatest of quality indicators $K_{i} / K_{i m}$ doesn't allow receiving its admissible value.

If necessary, data correction (mitigation of restrictions $O_{K}, O_{S}$ or working conditions $Y$ ) in a task (6) replacement of $M_{S D}$ on $M_{D}$ takes place, and after finding of minimax system $S_{M}$ check of an inequality (7) is carried out.

In such way, at optimal design of a communication network control system in two main modes of its functioning it is expedient to apply a minimin method when to find the solution in the analytical way and minimax, when the solution is found by method of iterations.

\section{References}

1. Беркман Л. Н. Багатокритеріальна оптимізація параметрів мереж. / В. Б. Толубко, Л. Н. Беркман, Л. О. Комарова, Є. В. Орлов // Журнал «Телекомунікаційна та інформаційні технології. - К., 2014. №4 - c. 4-12.

2. Беркман Л. Н. Інваріантність систем управління конвергентними мережами. / Л.Н. Беркман, Л.О.Комарова, І.О. Бойко // Наукові записки Українського НДІ зв’язку. - К., 2014. - № 29 - с. 11-16.

3. Беркман Л. Н. Архітектурна концепція TINA // Одеса: праці УНДІРТ, № 4, 1999, с. 4-10.

4. Беркман Л. Н. Інваріантність систем управління // «Зв'язок». К - 2000: № 2, с. 30-32. 
5. Gumennuy, D. A. "Hybrid Control Method for Stabilizing if Walking Robot on Irregular Surface Using Plantar Pressure Sensors./Dmytro Gumennuy, Mikhail Tkach, Alexey Chkalov. "ECCOMAS Multibody Dynamics (2013): 1-4. 